\title{
Beauty Is One With These
}

By John E. Nixon, Wauchope

You ask me for a list of lovely things:

These will I name for you-

The soft green of the poplar's emerald hue;

The deep blue of the sky that April brings,

Half seen through clouds; moonbeams that dance and shake

On moving waters; the green gold light that lingers

In wooded groves, and little winds that make

Dark shadows on a pool's tranquility.

Frost laid by Winter's fingers

On window panes by night; starshine at dawn,

Or the wide ocean's blue immensity.

Are these not lovely things?

The music of the song the thrasher sings;

Sunlight on dew, and dew tracks on a lawn;

Blue shadows on the snow as evening falls.

The gleam of light on china and on glass;

Dim colours in the bricks of ancient walls;

Rainbows and bubbles, and the yellow gold

On spreading beds of opening daffodils.

The light of sunset thrown on barren hills;

The slow change of the seasons as they pass.

Bare boughs and twigs against a winter sky;

The sheen of pearl; the cold

Hard light of diamonds; the soft sigh

Of stirring trees when wind the forest fills.

Voices of children and the songs they sing.

The smile of childhood is a lovely thing!

-All laughter, when its source is innocent-

Men spent in years, yet in their age content;

And women, silver-haired and quiet eyed.

Beauty is one with these.

Beauty is everywhere for one who sees,

And only hides from those who from her hide. 